\section{V/A 議事録には細心の注意}

国際の場で非常に重要なのは議事録である.ビジネスの世界 では当然のことであるが，学術界に生きている我々は，それを 失念してしまうケースがあるようだ. 他の会議も同様であろう が，ITU-T においては，口頭の発言よりも議事録が優先する. そのため, 会議で自分で発言したこと, 議論したことが正しく 議事録に記載されているか，また，ほかの人の発言が都合良く 記録されていないかを，しっかりと確認する必要がある. 逆に 言えば，毎回議事録に少しずつ自分たちの都合の良いように記 述してもらうことができれば，いつの間にか，多くのステーク ホルダが自分の規格を支持していることになる.

\section{6 これから標準化に関わる人へ}

以上のように，標準化活動は研究者にとって大变意義のあ るものであり, 社会へのインパクトも大きい. また, 決して 敷居の高いものではなく，信念に従い努力を重ねることによ り，成果を創造することができるものである．標準化をする 際には，是非，自分のサポー夕を作って頂きたい，国際の場 にいるコミュニティから信頼を獲得するだけでなく，国内の ステークホルダ，そしてその中に含まれるはずの自らの組織 の方々にもしっかりと自らの活動の重要性を伝え, サポータ になってもらうことが非常に重要であると私は思っている. 「研究ができる未標準化ができる」ではない，だからこそ， しっかりとサポータを作り, 彼らに重要性を伝えていくこと が重要である.

標準化活動には，百戦錬磨の人だけでなく，より若い人が 参加して頂くことを望んでいる．標準化の場で，そこでの活 動を通じて成長していくことも，研究者として非常に有用で ある．研究と標準化は技術の両輪であり，技術の進展に必要 な相乗効果を持っていると私は信じている.

文 献

(1) International Telecommunication Union's Telecommunication Standardization Sector, http://www.itu.int/ITU-T/

(2) Internet Task Engineering Force, http://www.ietf.org

（3）高橋健志, “ITU-T 勧告 X.1500: サイバ一セキュリティ情報交換 フレームワーク ," ITU ジャーナル, vol. 42, no. 2 pp. 39-43, Feb. 2012.

(4) T. Takahashi, Y. Kadobayashi, and H. Fujiwara, "Ontological approach toward cybersecurity in cloud computing," Int. Conf on Security of Information and Networks, ACM, Sept. 2010.

(5) T. Takahashi, K. Landfield, T. Millar, and Y. Kadobayashi, "IODEF-extension to support structured cybersecurity information," draft-ietf-mile-sci-05.txt, IETF draft, Oct. 2012.

高橋健志 (正員)

Tampere University of Technology (研究員), 日本学術 振興会 (特別研究員), (株)ローランド・ベルガー（コンサル タント) を経て，2009から現職。情報通信プロトコル，サイ バーセキュリティ情報, 及びマルチメディア符号化に関する研 究に従事. 博士 (国際情報通信学).

\section{IEEE1888 標準化活動 \\ 一コミュニティ監視・制御システム のオープン化を目指して一}

東京大学

落合秀也

Hideya Ochiai

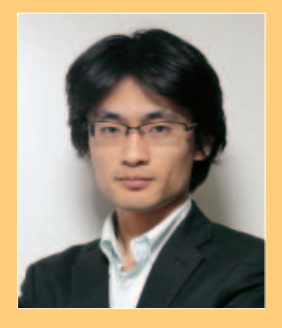

\section{1 まえがき}

あらゆるものがディジタル化・情報化されるユビキタス時 代は, 2010 年代, ビル設備や電力計測の業界にも到来した. 今や，スマート端末やクラウドサービスを使った「電力の見 える化」や「ビル設備の管理」は当たり前となり, これらの開 発に携わる業界の幅も急速に広まりを見せている.

このような時代の到来を控えた 2000 年代後半, 我々, グ リーン東大工学部プロジェクト（現, 東大グリーンICT プ ロジェクト ${ }^{(1)}$ ) の標準化活動はスタートした.この活動の中 で，上述のような時代の変化に合わせて設計された通信規格 FIAP $^{(2)}$ (Facility Information Access Protocol) は, 計 測や制御に関わる様々なソフトウェアコンポーネントやデー タベースを比較的容易に接続することを得意とし，インター ネット上で自由にデータ交換をできるようにした。我々は, この規格を IEEE などの標準化団体で提案し，現在は，IEEE 1888-201 $1^{11}$ 標準規格となっている.

この活動の原点には, 誰もが工学的に困難なく始められるオ一 プンな共通通信基盤を構築するべきである, という基本理念が ある，単に規格化や標準化するだけでは意味がなく，開示可能 なオープンな技術を開発し，誰にでも開かれた共通基盤を構築 していくことが大切なのである. これまでの設備ネットワーク規 格は, オープンと言われながらも, 公開されている技術情報は僅 かであり, 大手企業でなければ, その市場に参入し, 機器やサー ビスを開発することは困難であった。 中小企業や大学等の研究 機関が活動できるような場は，ほとんど存在していなかった。

\section{2 標準化提案活動}

我々の標準化提案活動は, IEEE 1888 委員会及び米国 $\mathrm{ASHRAE}^{2)}$ の BACnet 委員会 ${ }^{3)}$ での活動が主となっている.

IEEE 1888 委員会は，2008 年に立ち上げられた，比較 的新しい標準化委員会である。通信規格 IEEE 1888-2011 は，年数回の会合の中で審議されて通信仕様が提案され，

1) IEEE 1888-2011: 2011 年に IEEE で承認された Ubiquitous Green Community Control Network Protocol(UGCCNet) 通信規格.

2) ASHRAE: American Society of Heating, Refrigerating and Air-Conditioning Engineers $の$ 略称.

3） BACnet 委員会 : Building Automation and Control Network （BACnet）の仕様を策定する委員会. 


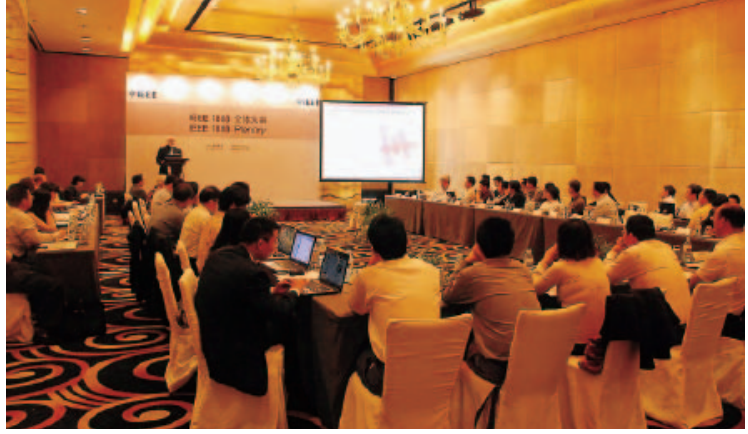

図 1 IEEE 1888 標準化委員会の様子

2011 年に策定されたものである. 現在, IEEE 1888 委員 会では，図 1 に示すような会合を定期的に開催し，サブ標準 1888.1，1888.2，1888.3 の策定作業を行っている.

標準化活動を行う上では，チェアと内容について意思共有 を行うために, 会合の前後で顔を合わせて予備会合を持つこ とは少なくない，また，会合の前後数週間には，メールなど でドキュメントを頻繁に交換し合うなどする. 会合の中では, 事前の打合せどおりに審議が進められているかを確認しなが ら，参加者全員で同意を取っていくことになる．場合によっ ては議論が紛糾し，審議が長引くこともある.

このような活動を通して, 通信規格案は関係者間で審議さ れ，最終的に承認されて，策定される.

\section{3 開かれた技術の開発}

我々の標準化活動は，標準といわれる仕様を提案し，それを 策定することだけが目的ではない. 誰もが活動できるオープン な場を築き上げることが，何よりも大切であると考えている.

メーカーにとっては, システムの構成部品を製造すること は，事業の柱となる．そのため，製造ノウハウなどの技術は， 利益を生み出す要として, 通常は, 極秘事項とされる．もち ろん，それは当然のことであるが，企業が中心となって進め られる標準化の場合, 極秘化が同時に発生するため, 規格化 だけが先行し，その技術ノウ八ウは世の中には，なかなか流 通しないという現象が発生する。 このような現象は，標準化 の本来の趣旨からして, 健全とは言い難く, できる限り避け られるようにしなければならない.

開かれた技術の開発は，オープンな標準化にとっては，な くてはならない存在である．例えば，「プロトコルスタック (実装)」は，その通信を行う上で必要な技術である。これは 誰かが開発しなければならない。企業が開発した場合には, 企業秘密の対象となるために，そのソースコードは誰もが自 由に使える形で広まることはまずない，しかし，中立的な立 場にある人々が，このような標準規格に基づくパーツを開発 し，世の中に広く供給するようになれば，開かれた技術の流 通が生まれることになる.

このような背景のもと, 我々はIEEE 1888 に関して, 次 のようなオープン技術を積極的に開発し，提供している ${ }^{(3)}$.

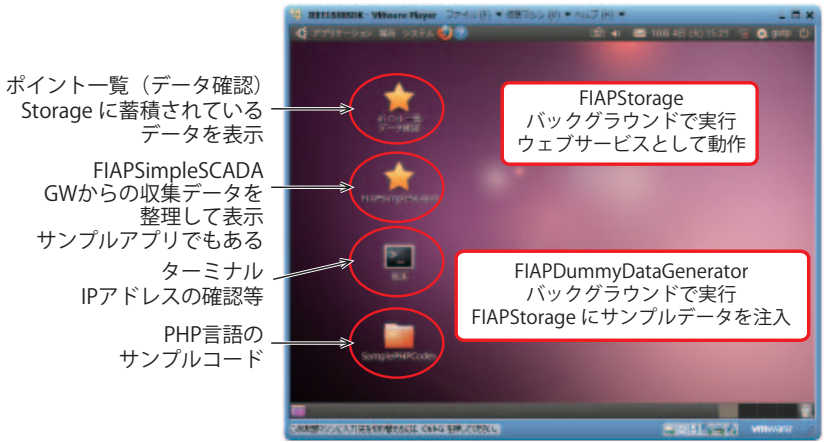

図 2 IEEE 1888 ソフトウェア開発キット

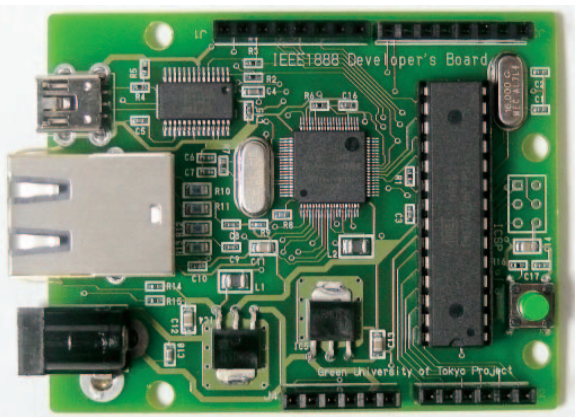

図 3 IEEE 1888 通信ボード

電力計の検針データの収集や, ネットワーク上のデマンド警報情報 のブザーによる通知など, 各種アプリケーションで利用されている.

(1) IEEE 1888 ソフトウェア開発キット (図 2)：IEEE 1888 部品を開発するためのツールが盛り込まれた開発キット である.C\#, Java, PHPなどの言語を用いたプログラ ミング方法から，ビルド，実行，確認方法などがマニュ アルで解説されている.

(2) IEEE 1888 通信ボード (図 3) ${ }^{(4)}$ : Arduino ${ }^{(5)}$ 互換の 通信ボード. ソフトウェアにより IEEE 1888 が実装さ れ，その技術はオープンになっている.

（3）参照機器 / 参照コード : Java 言語や C 言語による IEEE 1888 通信スタックや実装例を提供している.

（4）テスタ：IEEE 1888 サーバを実装した際に，そのサーバ が正しく実装されているかどうかを検証するツール.

上述のような，オープン技術を開発するだけでなく，各社 が開発した IEEE 1888 通信機器がお互いに正しく接続でき るかどうかを検査する「相互接続試験」を定期的に開催して いる. 2011 年 3 月, 2012 年 3 月, 2012 年 10 月は東 京大学で開催され，30 種類以上の IEEE 1888 通信機器が

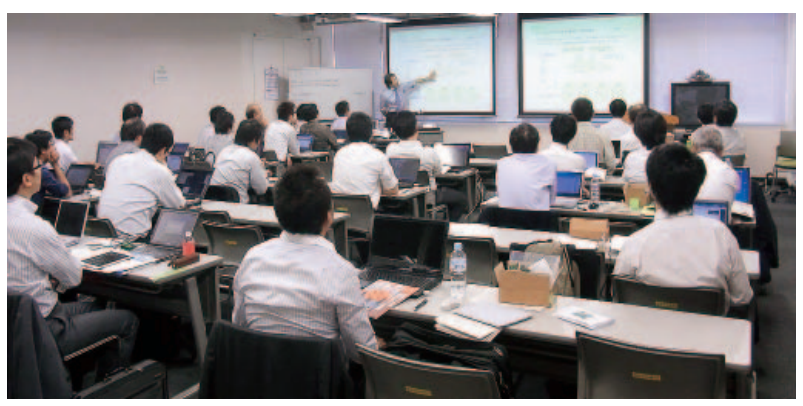

図 4 相互接続試験に先立って行われた IEEE 1888 実践 ワークショップの様子（2012 年 10 月） 
持ち込まれている（図 4 は相互接続試験に先だって行われた 実践ワークショップの様子)。これらのオープンな標準技術 の開発は，研究活動に広く貢献するだけでなく，次に述べる 事業化 (そして社会での利用) につながっていくことになる.

\section{4 事業化の支援}

IEEE 1888 通信規格を実装する機器を開発し，それを商 品化していくためには，様々なステップが必要になる．具体 的には，信頼性，保証，保守，対応，サポート体制などが整 備されなければ，商品としては成立しない。これは，金銭や 信頼関係が絡んでくる企業にとって，とても重要なことであ る.オープン技術単体には，このような体制は存在しないた め, これらを整備する必要がある（＝整備すれば事業として 成立する). 挑戦的な企業は，その辺りの体制を整備しなが ら，オープン技術を上手に利用し，次の時代の技術を事業の 柱にしていくことができる. 我々は，そのような企業ととも に事業化への道を模索・展開し続けている. その結果とし て, 現在, 10 社近くの中小のベンチャー企業が事業の一部 として IEEE1888 の開発やサービス展開を実施している. また，ある大手システムインテグレータは， 1,200 拠点への IEEE 1888 通信システムの導入を進めている.

\section{5 む び}

IEEE 1888 標準化活動は多くのメンバと共同で進められ ている活動である．仕様の提案をし，技術を開発し，事業化 を支援するというコンセプトの下，オープンな場をまさに整 備しているところである.

文 献

（1）江崎浩, 落合秀也, “東大グリーンICT プロジェクト, ”信学誌, vol. J94-B, no.10, pp.1225-1231, Oct. 2011.

(2) H. Ochiai, M. Ishiyama, T. Momose, N. Fujiwara, K. Ito, H. Inagaki, A. Nakagawa, and H. Esaki, "FIAP: Facility information access protocol for data-centric building automation systems," IEEE Infocom, M2MCN Workshop, April, 2011

(3) IEEE1888 ツール公開ページ, http://gutp.jp/fiap/kit.html

（4）落合秀也, 井上博之, 寺西裕一, 江崎浩, “センサ・アクチュエー 夕接続対応インターネット通信ゲートウェイの設計と試作, ”信 学技報, IA201 1-94, March 2012

(5) Arduino, http://arduino.cc/

\section{落合秀也 (正員)}

平 18 東大·工·電子情報工学卒. 平 23 同大学大学院情報理 工学系研究科博士了. 同年, 同大学大規模集積システム設計 教育研究センター助教, 現在に至る. 博士（情報理工学）（平 23-03, 東大). 広域センサネットワーク, 遅延耐性ネットワー ク研究の他, IEEE 1888 及び ASHRAE での設備ネットワー ク標準化活動に従事.

\section{これから国際標準化活動に 参加される方に伝えたいこと 〜 IEEE 1900.4の経験から〜 独立行政法人 情報通信研究機構 石津健太郎 \\ Kentaro Ishizu

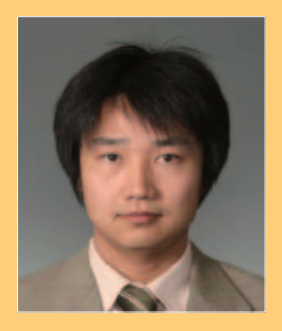

\section{1 まえがき}

IEEE 802.11 は無線 LAN の規格であるということはよ く知られていると思います. 規格は対象とするシステムに応 じて様々に定められ，その策定作業は標準化活動と呼ばれま す、標準化活動の中でも世界的に共通となる規格を目指す国 際標準化活動は, 世界中の技術者や研究者が議論を重ねて一 つの規格を作り上げていく地道な作業です．国際標準化活動 を行う組織として IEEE (The Institute of Electrical and Electronics Engineers）があり, 本来は米国の学会という 位置付けではありますが，そこで策定された規格は世界中で 参照されることが多く, 実質的な国際標準規格を策定する会 議としても機能しています.

国際標準化活動の中でも, IEEE P1900.4 WG はネット ワーク機器や端末が協調することにより最適な周波数の利用 が可能にするコグニティブ無線ネットワークの構成技術につ いて規格化を行っていますが, 私は 2007 年 2 月の WG 発 足当初から一貫して出席して, 提案, 議論を行いながら, 仕 様が策定される過程とともに 5 年以上を歩んでくることが できました. 国際標準化活動は研究活動とも密接に関係して おり, 研究の成果を実用化に結び付ける手段として, あるい は研究プロジェクトや技術動向の最新情報を入手する場とし て, 更には, 世界の第一線で活躍するメンバと知り合う場と しても, 非常に有用な機会です.これから国際標準化活動に 参加される方のために，その雾囲気や実際に何が行われてい るのか, 何が求められているのかを, 私の経験に基づいてお 伝えします。

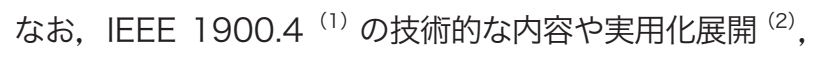

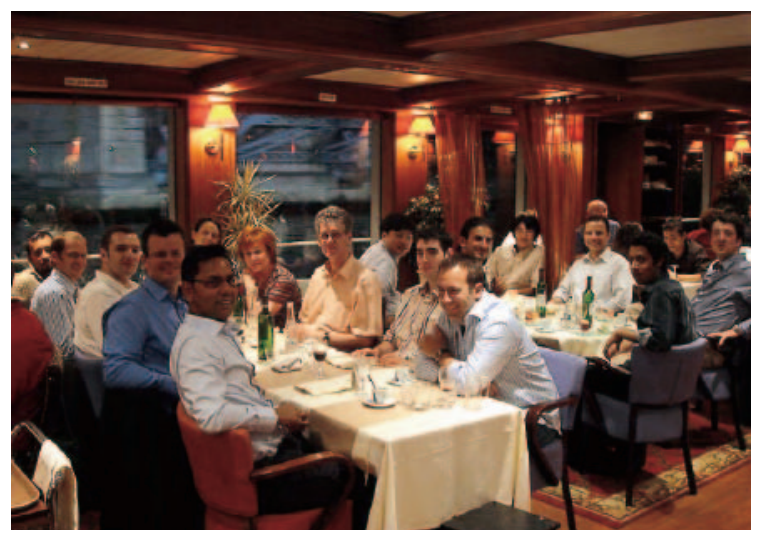

図 1 第 3 回 IEEE 1900.4 会議後のソーシャルイベント (2007 年 6 月パリ) 